\title{
Hygrothermal Influence on Delamination Behavior of Graphite/Epoxy Laminates
}

Amar Garg

Ori Ishai, Ames Research Center, Moffett Field, California 


\section{Hygrothermal Influence on Delamination Behavior of Graphite/Epoxy Laminates}

Amar Garg and Ori Ishai

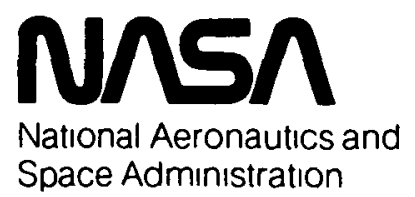


HYGROTHERMAL INFLUENCE ON DELAMINATION BEHAVIOR

OF GRAPHITE/EPOXY LAMINATES

Amar Garg and Ori Ishai

NASA Ames Research Center, Moffett Field, California

\begin{abstract}
The hygrothermal effect on the fracture behavior of graphite/epoxy laminates has been investigated as part of an overall effort to develop a methodology for damage-tolerance predictions in advanced composite materials. Several T300/934 laminates were tested using a number of specimen configurations (double cantilever, compact tension, and cracked lap shear) in order to evaluate the effects of temperature and humidity on delamination fracture toughness under Mode I and Mode II loading. The specimens were exposed to different humldity levels and temperatures for varying periods of time prior to testing. The pre-exposed specimens were tested under room conditions, and fracture energies during initiation and propagation were estimated. Acoustic emission was used to detect crack infiation. It was indicated that moisture has a slightly beneficial influence on fracture toughness or critical strain energy release rate during Mode I delamination, but has a slightly deleterious effect on Mode II delamination and Mode I transverse cracking. The failed specimens were examined by SEM and topographical differences due to fracture modes were 1dentified. The effect of moisture on fracture topography could not be distinguished.
\end{abstract}




\section{INTRODUCTION}

Delamination has long been recognized as one of the major failure modes in fiber-reinforced composite materials. In general, delamination will occur prior to fallure in laminates loaded efther monotonically or cyclically and is the most prevalent life-limiting growth mode [1-3]. A laminate when loaded to fallure may have several possible damage modes [4] but only a few actual failure modes [2]. Inftial damage occurs as matrix cracklng in plies having a significant tensile stress perpendicular to the fibers ( $1 . e .$, the $90^{\circ}$ plies). This event is generally referred to as first-ply-failure. The process of matrix-crack initiation continues in the $90^{\circ}$ plies, and in other off-axis plies as the load is monotonically increased or cycled. Once matrix cracking achieves saturation, crack coupling or Interfacial debonding begins which may then culminate in delamination growth. This latter phase of damage occupies a major portion of the fatigue life of a componenit. Although delamination does not always lead to immediate or catastrophic fallure of a component, it may significantly alter structural performance. The importance of understanding and predicting delamination behavior in the service environment is obvious; and the effect of moisture combined with temperature may be critical during the initial damage stage.

One of the earlier works to predict the onset of edge delamination was that of O'Brien [5] who used a simple analysis based on stiffness reduction during delamination. Using this method and the experimental results obtained for the delamination of an unnotched $[ \pm 30 / \pm 30 / 90 / \overline{90}]_{s}$ graphite/epoxy laminate, he successfully predicted the onset of 
de lamination in $\left[+45_{n} /-45_{n} / 0_{n} / 90_{n}\right]_{s}(n=1,2,3)$ laminates. He also formulated a relationship which predicts the propagation of delamination during cyclic loading.

Law [6], using a finite-element approach and a mixed-mode fracture criterion, has been able to predict the onset of free-edge delamination in $\left( \pm 25 / 90_{n}\right)_{s}$ laminates made of $\mathrm{T} 300 / 934$ graphite/epoxy material. His predicted results agree well with experimental observations. He has concluded that thermal residual stresses caused by cool-down after cure plays a significant role in determining fracture load. For example, it was found that thermal residual stresses contributed approximately $50 \%$ and $20 \%$ to matrix cracking and free edge delamination, respectively. Kim and Soni [7], Crossman and Wang [8], and Wang [9] have also successfully demonstrated the various approaches to predict onset of delamination.

The success of analytical predictions depends upon the right choice of interlaminar fracture energies which must be determined experimentally using proper specimens. Since there is no standard specimen for the study of the delamination fracture, various types of specimens [1, 10-19] have been used. The double cantilever beam (DCB) specimen for Mode I, and the cracked lap shear (CLS) specimen for Mode II (or mixed mode) appear to be most successful.

Most of these past works have been performed using dry or nearly dry specimens with only minor attention pald to the hygrothermal influence on delamination behavior. In contrast, the present study attempts to characterize the effects of moisture. Mode I and Mode II interlaminar fracture energies using $D C B$ and CLS specimens have been determined for dry and wet conditions and are presented. Although Mode I delamination 
along the $0 / 0,0 / 90$, and $+45 /-45$ interfaces was studied, only the data for the $0 / 0$ interface are reported here. No useful data were obtained for the other interfaces since the crack wandered between plies. Additionally, a minor effort is made to characterize transverse cracking under Mode I loading.

\section{EXPERIMENTAL PROCEDURE}

\section{Test spectmens}

A double cantilever beam (DCB) specimen of a design similar to that used by Wilkins [1] was used to study Mode I delamination. Thts spec1men, shown schematically in Fig. 1, consisted of a 25-mn wide and 230-mm long coupon bonded at one end to hinged tabs for the application of load perpendicular to the interlaminar layer. Initiation of delamination along the interlaminar layer was accomplished by the insertion of a piece of mylar tape, 0.025-mm thick and 30-mm wide, between the appropriate plies at the time of fabrication. Three types of layups were prepared $-[0]_{16},[0]_{20}$, and $[0]_{26}$ - with the mylar tape located at mid-thickness.

Transverse cracking, perpendicular to the interlaminar layer and parallel to the fibers under Mode I loading, was studied using a 50-mm wide compact tension (CT) specimen of the type recommended by ASTM E399 [20] for metallic materials. The specimens were notched parallel to fibers using a diamond-impregnated wire saw approximately 0.2 mo in diameter. A single $[0]_{16}$ laminate was used in this investigation. Mode II, or mixed Mode I and Mode II, loading was investigated using a cracked-lap-shear (CLS) specimen shown in Fig. 2. The specimen 
was 23-mm wide and 230-m long having the lay-up as shown in the figure. A mylar tape was implanted between plies 6 and 7 using the same procedure as previously described for the DCB specimens.

Environmental exposure

A11 specimens were dried at $70^{\circ} \mathrm{C}$ under vacuum unt1l no additional weight loss was observed. Following drying, some specimens were immersed in $70^{\circ} \mathrm{C}$ water and some were exposed to a $70^{\circ} \mathrm{C} / 50 \%$ relative humidity condition. Specimens with different moisture levels were tested at room temperature. In addition, a few dry $[0]_{20}$ specimens were tested at $127^{\circ} \mathrm{C}$ after presoaking at this temperature for about $2 \mathrm{hr}$.

\section{Test method}

Double cantilever beam specimens were tested under displacement control using a 120 Newton load cell on a $50 \mathrm{kN}$ standard servo-hydraulic test machine. The specimens were originally loaded to initiate and grow a crack about 50-mm long. Load was then applied at a constant crosshead displacement rate until the crack grew some distance. The specimen was unloaded and the process was repeated to achieve the desired delamination growth. The crosshead speed was $0.08 \mathrm{~mm} / \mathrm{sec}$ for short cracks and was increased to $0.25 \mathrm{~mm} / \mathrm{sec}$ for longer cracks (beyond $\sim 90 \mathrm{~mm}$ ). Load was recorded as a function of crosshead movement. In addition, delamination growth for $[0]_{16}$ and $[0]_{26}$ specimens was monitored by acoustic emission (AE). The $A E$ system was set at $90 \mathrm{~dB}$ overall gain, and the RMS was continuously recorded durling the crack growth, and $A E$ counts were read from a visual display.

The cracked-lap shear specimens were also tested under displacementcontrol conditions at a constant crosshead displacement rate of 
$6.35 \times 10^{-6} \mathrm{~m} / \mathrm{sec}$ on the $50 \mathrm{kN}$ test system. Specimen extension about the notch was measured using an extensometer with 152-mm gage length. Curves of axial load vs extension were recorded on an $X-Y$ plotter as a function of crack length. An optical microscope was used to observe the crack extension. Acoustic emission was also used to mont tor the crack inttiation and propagation.

The compact tension specimens were tested in a similar manner to the above except a smaller load cell was used. Load vs ram displacement was recorded. Tests were performed at room temperature in a laboratory air envi ronment and at $127^{\circ} \mathrm{C}$.

DATA ANALYSIS

The critical strain-energy release rate for a linear elastic material is defined as:

$$
G_{c}=\frac{P^{2}}{2 W} \frac{\partial C}{\partial a}
$$

here $P_{C}$ is the critlcal load at which the crack initiates, $C$ is the specimen compliance, $a$ is the crack length, and $W$ is the specimen width. The parameter $\partial C / \partial a$ is the slope of the $C$ vs a curve. The compliance, $\mathrm{C}$, is the slope of load-displacement curve and is defined as

$$
C=\frac{\delta}{P}
$$

where $P$ is the applied laod, and $\delta$ is either opening displacement of double cantilever beam specimen for Mode I, or the extension for cracked lap shear specimen for mixed mode loading. 


\section{Mode I delamination}

The DCB specimen used in the present study can be considered as two cantilevers, joined at one end, i.e., at the crack tip. Substituting the load-displacement relationshlp for such beams [1] into Eqn. (1), Mode I critical strain energy release rate or fracture toughness, G Ic' can be written as

$$
G_{I c}=\frac{3 \alpha a^{2} P_{c}^{2}}{2 W}
$$

where

$$
\alpha=\frac{c}{a^{3}}
$$

Equation (3) was derived assumlng a linear elastic behavior without shear deformation. For such an assumption, a plot of compliance, C, vs $a^{3}$ should be a straight line. Such a plot, using typical data from the present study, is shown in Fig. 3. As can be seen, the cubic relationship is valid and the assumption of linear elastic behavior is correct. It is obvious from Eqn. (3), that if the fracture toughness, $G_{I c}$, is to be independent of crack length a, then the critical load, $P_{C}$, must be inversely proportional to a. Typical data from the present study are shown in Fig. 4. It can be seen from this figure that $\log \mathrm{P}$ vs $\log$ a 1 a straight line leading to the relation:

$$
\begin{gathered}
P_{c} \propto \frac{1}{a} \\
P_{c} a=B
\end{gathered}
$$

or

where $B$ is the constant of proportionality. Substituting Eqn. (5)

into Eqn. (3), we obtain the expression for fracture toughness:

$$
G_{I c}=\frac{3 \alpha \beta^{2}}{2 W} \text {. }
$$


Mode II delamination

To estimate Mode II delamination fracture toughness, compliance for various values of crack length a was obtained from load-displacement curves and is shown in Fig. 5. From this figure the value of $\partial C / \partial a$ was determined. This along with the critical load, $P_{c}$, determined from the load vs displacement curves yields $G_{c}$ from Eqn. (1). The calculated $G_{C}$ is the sum of all the components of $G$ for Modes I, II, and III. It was observed that the experimental values of critical load $P_{c}$, correspond to crack advancement along the centerline of the specimen, where Mode III effects disappear. Because of this, Mode III effects can be ignored. For such a case, by using finite element analysis, Wilkins [1] has shown that Mode II contributes to about $75 \%$ of the total strain energy release rate and remaining $25 \%$ is contributed by Mode $I$. Thus, Mode II strain energy release rate $G_{\text {IIc }}$ is approximated by

$$
G_{\text {IIc }}=0.75 G_{c}
$$

\section{Transverse cracking}

The critical stress intensity factor $K_{I c}$ for compact tension specimen of an isotropic material is given by [20]

$$
K_{I c}=\frac{P_{c}}{t \sqrt{w}} f\left(\frac{a}{W}\right)
$$

where $P_{C}$ is the critical load to failure, and $a, t$, and $W$ are notch depth, specimen thickness and width, respectively. The function $f(a / W)$ is given by

$$
f\left(\frac{a}{W}\right)=\sqrt{\frac{a}{W}}\left[29.6-185.5 \frac{a}{W}+655.7\left(\frac{a}{W}\right)^{2}-1017.0\left(\frac{a}{W}\right)^{3}+638.9\left(\frac{a}{W}\right)^{4}\right] .
$$


For a homogeneous orthotroplc linear elastic material, the strain energy release rate, $G_{I}$, for a crack lying along a plane of symmetry is related to the stress intensity factor, $K_{I}$, by the expression [21]

$$
G_{I}=\phi K_{I}^{2}
$$

where

$$
\phi=\left(\frac{1}{2 E_{11} E_{22}}\right)^{1 / 2}\left[\left(\frac{E_{11}}{E_{22}}\right)^{1 / 2}+\frac{E_{11}-2 v_{12} G_{12}}{G_{12}}\right]^{1 / 2} .
$$

The values $E_{11}, E_{22}, V_{12}$, and $G_{12}$ are the engineering elastic constants of the material.

RESULTS AND DISCUSSIONS

Typical load-displacement curves for Mode I delamination in DCB specimens are shown in Figs. 6 and 7 for dry and wet conditions, respectively. It is seen that, for dry laminates, the curves are linearly increasing until the onset of delamination. Beyond this point, the load slowly decreases as the crack propagates, whereas the specimens $\left([0]_{16}\right)$ which were exposed to $70^{\circ} \mathrm{C} /$ water for 62 days $(w=2.1 \%)$ and were almost saturated, behaved somewhat different. For these, the load displacement curves are initially linear, but tend to be nonlinear towards the maximum load, indicating an increase in compliance unt1l the onset of delamination. This latter behavior is similar to that observed in metallic materlals where the deviation from linearity is due to yielding or to the plastic zone formation around the crack tip. As the matrix of the laminate is plasticized (or softened) due to absorption of motsture, the nonlinearity is attributable to matrix yielding. The other 
phenomenon observed with these wet specimens is a sudden delamination growth and a drop in load (Fig. 7). This behavior is not observed in the specimens which were either exposed to $70^{\circ} \mathrm{C} / 50 \% \mathrm{RH}$ or to $70^{\circ} \mathrm{C}$ water for a short time. This observation suggests that the rapid fracture in case of wet specimens is the result of prolonged exposure to hot water and also may be the result of the formation of some weak zones. It is noticed from optical examination of the fracture surfaces that regions with spontaneous crack growth are darker than are regions of slow crack growth as shown in Fig. 8.

Acoustic emissions (AE) responses for Mode I delamination growth in dry and wet specimens are shown in Fig. 9. Plotted is AE response in terms of RMS voltage as a function of time. As can be seen, the RMS amplitude from a dry specimen is higher than from a wet. A reduction in RMS output due to moisture content has also been observed by Hamstad [22]. This indicates that the motsture absorption in graphite/epoxy causes attentuation of the AE signal, and thus, may serve as a useful NDT tool in establishing the environmental history of such materials. The number of counts was also determined during delamination. A typical plot of AE counts vs delamination growth is presented in Fig. 10 for a few dry specimens. Counts are seen to be linearly increasing with the delamination growth, $\Delta a$, and are not influenced by laminate thickness. Moisture seems to reduce the $\mathrm{AE}$ counts as indicated in Fig. 11 which is a typical plot of number of AE counts per unit crack surface area, $n$, as a function of moisture content for specimens $\left([0]_{16}\right)$ exposed to $70^{\circ} \mathrm{C}$ water. $n$ seems to be decreasing almost linearly with moisture level in 
the specimens. A summary of $n$ observed for Mode I delamination is shown in Table 1.

Fracture toughness for Mode I delamination was determined using the load-displacement curves and the Eqns. (2), (4), (5), and (6). The values of $G_{I c}$ determined for various test conditions of the present study are summarlzed in Table 1. The variation of $G_{\text {Ic }}$ as a function of moisture content is shown in Fig. 12. As can be seen from the table and figure, $G_{I c}$ in specimens which were exposed to $70^{\circ} \mathrm{C} / 50 \% \mathrm{RH}$ exhibiting absorbed molsture contents up to $0.5 \%$ was unchanged, whereas spectmens which were immersed in $70^{\circ} \mathrm{C} \mathrm{H}_{2} \mathrm{O}$ with higher moisture content showed some increase in $G_{I c}$. In the latter case, this increase in $G_{I c}$ may be the result of plastification of the matrix as a result of moisture absorption. In the former case, moisture appears to have not penetrated the delaminating surface and it remains almost dry. An increase in temperature is found to have an effect similar to moisture absorption, as seen from Fig. 13. Here, $G_{I c}$ is seen to increase with an increase in temperature. Once again, the increase in toughness is most probably associated with an increase in the ductility of matrix due to an increase in temperature. An increase in interlaminar fracture toughness due to moisture absorption and temperature has also been observed by Wilkins [18] for AS 3501-6.

It is seen from the results sumarized in Table 1 , that $G_{\text {Ic }}$ for $[0]_{16}$ and $[0]_{20}$ laminates are about the same and are lower than that observed for $[0]_{26}$ laminates. In the latter case, this difference is most probably due to some fiber involvement as suggested by the somewhatroughened fracture surface. 
Table 2 is a summary of Mode I delamination fracture toughness obtained by other investigators for a number of composite systems. It is seen that $G_{I c}$ obtained in the present study agrees falrly well with $G_{\text {Ic }}$ of similar graphte/epoxy systems. Also as seen from Table 2, $G_{\text {Ic }}$ for T300/934 is between that for T300/5208 and AS 3501-6.

In order to compare Mode I interlaminar fracture energy to that observed for transverse cracking along the fiber direction but perpendicular to interlaminar plane, a few compact tension (CT) specimens, [0] ${ }_{16}$, notched parallel to fibers, were tested in both the dry and wet conditions. Table 3 is a summary of this data. Comparing these data with those obtained for delamination (Table 1), it can be seen that transverse cracking requires almost four times the fracture energy. It was determined that the fracture surfaces from transverse cracking were considerably rougher than that observed from delamination. In transverse cracking, there is no clear interface for the crack to follow and fiber involvement is the apparent cause of the higher fracture energy.

The effect of moisture on transverse fracture energy, as seen in Table 3, is to reduce $G_{I c}$. This is in contradiction to that observed for delamination (Table 1). This change in the environmental influence appears to be due to differences in the fracture mechanism. Delamination is dominated by matrix fracture, whereas transverse fracture is controlled both by fiber-matrix interface failure, and matrix fracture. It must be deduced that moisture-induced reduction in transverse fracture toughness is the result of a greater weakening of the fiber matrix interface than the increase by matrix plastification. 
M1xed-mode delamination was studied using cracked-lap-shear (CLS) specimens. Typlcal load-displacement curves from these specimens are shown in Fig. 14. The load-displacement curves are seen to be linear up to the point of crack 1nitiation. Beyond this point, the curves become nonlinear due to grack growth. No difference in this general behavior was observed between wet and dry specimens. Mode II delamination fracture toughness, $G_{I I c}$, is shown in Fig. 15 as a function of moisture content in the laminate. Because of the limited number of specimens and associated scatter, it is difficult to determine whether fracture toughness is changed with moisture content. However, the average value of $G_{I I c}$ for the wet composite is about $12 \%$ lower than that for the dry. Similar observations have been reported by Wilkins [18] for AS 3501-6 and T300-6K/V378A and are shown in Table 4. Similar to the results for $G_{I c}, G_{I I c}$ for $T 300 / 934$ is seen to lie between $G_{I I c}$ for T300/5208 and AS 3501-6. These results Indicate that the system T300/934 is more brittle compared to T300/5208, but less brittle when compared to AS 3501-6.

The fracture surfaces of all specimens were examined using a scanning electron microscope (SEM) In an effort to identify any characteristic morphological differences. SEM fractographs from the various speciments are presented In F1gs. 16 to 18.

A typical fracture surface of Mode I delamination is shown in F1g. 16 and strongly suggests Mode I delamination is matr1x-dominated fracture. The dominant feature of this fracture is matrix cleavage, indicative of a tensile fracture of a brittle materlal. The fracture is marked by river patterns, chevron markings, and a cleavage-like branched 
structure in the matrix material between fibers. The river pattern and chevron markings are simflar to the cleavage fracture patterns observed in metallic materials [27]. The explanations for such markings have been proposed by several authors [28-31]. It is important to note that these markings, particularly chevron markings, can be used to establish the direction of crack propagation and location of the orfgin of cracking. Another feature evident in Fig. 16 is the fiber surface, free of matrix residue, indicative of a weak interfacial bond. This was not a dominant behavior and occurred only in selected areas. Finally, the fracture surfaces of wet specimens falled by Mode 1 delamination were similar to dry specimens, and it appears that the moisture makes no significant change in fracture morphology.

The typical fracture surface of transverse cracked CTS specimens is shown in Fig. 17. As can be seen, fracture morphology is similar to Mode I delamination (Fig. 16), but with more fiber-matrix interface debonding. Again, the epoxy fracture surface is marked by features such as river markings and branched crack structures indicative of matrix cleavage failure. Again, wet specimens indicated no morphological differences from dry.

The typical fracture surface of mixed mode interlaminar fracture from CLS specimens is shown in Fig. 18. The fracture surface is seen to have hackles as the prime feature, indicative of shear fracture. The other features include fiber surfaces free of matrix residue, feather patterns with a fibrous structure, and some hills and valley structures. The wet specimens also showed features similar to those of dry and, thus, moisture did not affect the fracture surface morphology. 


\section{CONCLUSIONS}

The major results of this study are:

1) Interlaminar fracture toughness in Mode I delamination increases slightly with increased molsture content and increased temperature and is most probably the result of matrix plastification. Also, increased toughness appears to increase with surface roughness which may be the result of increased fiber involvement.

2) Transverse fracture toughness appears to decrease slightly with molsture content in the specimen and is most probably the result of a weakening of the fiber matrix interface bond.

3) Mode II fracture toughness appears to be slightly reduced by increased moisture content.

4) Acoustic emission can be used to detect the crack initiation. Moisture causes the attenuation of $\mathrm{AE}$ output and a reduction of the number of $A E$ counts.

4) Fracture surfaces exhibit some distinct morphological differences:

(a) Interlaminar fracture due to Mode I delamination is characterized by matrix cleavage, river patterns, chevron markings, and branched crack structures.

(b) Transverse fracture due to tensile loading is characterized by the features similar to those observed for Mode I delamination, but with increased amount of fiber matrix interface failure.

(c) Interlaminar fracture due to Mode II delamination is characterfzed by extensive epoxy hackles, fibers free of matrix residue and hills and valley structure. 
6) The moisture does not appear to significantly influence the fracture surface morphology of Mode I and Mode II delamination, or of Mode I transverse cracking.

\section{REFERENCES}

[1] D. J. Wilkins et al., Characterizing delamination grwoth in graphite-epoxy. ASTM STP 775, 168-183, Philadelphia, Pa. (1980).

[2] K. L. Reifsnider et al., Damage mechanics and NDE of composite laminates. Mechanics of Comp. Materials (edited by 2 . Hashin and C. T. Herakovich), Proc. of IUTAM, Blacksburg, Va., Pergamon Press, New York, 339-490 (1983).

[3] R. L. Ramkumar, Compression fatigue behavior of composites in the presence of delamination. ASTM STP 775, 184-210, Philadelphia, Pa. (1982).

[4] C. K. H. Dharan, Fracture mechanics of composite materials. J. Eng. Mat. and Technology, 100, 233-247 (1978).

[5] T. K. O'Brien, Characterization of delamination onset and growth in a composite laminate. ASTM STP 775, 140-167, Phlladelphia, Pa. (1982).

[6] G. E. Law, The fracture behavior of $\left( \pm 25 / 90_{n}\right)_{s}$ graphite/epoxy composite laminates. Presented at ASTM Conference on Effect of Defects in Composite Materials, San Francisco (1982).

[7] R. Y. Kim and S. R. Soni, Experimental and analytical studies on the onset of delamination in laminated composites. University of Dayton Res. Inst., Dayton, Ohio, Rept. UDR-TR-83-40 (1983). 
[8] F. W. Crossman and A. S. D. Wang, The dependence of transverse cracking and delamination on ply thickness in graphite/epoxy laminates. ASTM STP $775,118-139$ (1982).

[9] S. S. Wang, Fracture mechanics for delamination problems in composite materials. J. Comp. Mat. 17, 210-223 (1983).

[10] W. D. Bascom and D. L. Hunston, The fracture of epoxy and elastomermodified epoxy polymers. Adheston 6, edited by K. W. Allen, Applied Sc. Publishers, London, 185-210 (1980).

[11] J. Koutky, B. River, R. Ebewele, M. Luce, and K. S. Han, Evaluation of fracture energies of composites using cantilever beam techniques. Proc. Organic Coatings and Appl. Pol. Sc., American Chemical Soc., $48,822-825$ (1983).

[12] R. A. Turf and R. B. Pipes, Interlaminar fracture of composite materials. J. Comp. Mat. 16, 386-394 (1982).

[13] F. X. Charentenay, Delamination of glass fiber reinforced ployester. An acoustic emission stucy. ICM3 Cambridge, 3, 241-249 (1979).

[14] K. S. Han and J. Koutsky, Effect of water on the interlaminar fracture behavior of glass fiber-reinforced polyester composite. Composites 13, 67-70 (1983).

[15] D. F. Davitt, R. A. Schapery, and W. L. Bradley, A method for determining the Mode I delamination fracture toughness of elastic and visco-elastic composite material. J. Comp. Mat. 14, 270-285 (1980).

[16] K. S. Han and K. Koutsky, The interlaminar fracture energy of glass fiber reinforced polyester composites. J. Comp. Mat. 15, 371-388 (1981). 
[17] P. S. Vanderkley, Mode I - Mode II delamination fracture toughness of a unidirectional graphite/epoxy composite. Master Thesis, Texas A \& M University $(1981)$.

[18] D. J. Wilkins, A comparison of the delamination and environmental resistance of a graphite-epoxy and a graphite-bismaleimide. Naval Afr Systems Command, NAV-GD-0037 (1981).

[19] W. D. Bascom, J. L. Bitner, R. J. Moulton, and A. R. Siebert, The interlaminar fracture of organic-matrix woven reinforcement composites. Composites 10, 9-18 (1980).

[20] Annual Book of ASTM Standards, American Society for Testing and Materials, Philadelphia, E399-78 (1978).

[21] P. C. Paris and G. C. Sih, Stress analysis of cracks. ASTM STP 381 , 30-81 (1964).

[22] M. A. Hamstad, Local characterization of fiber composites by acoustic emission. Army Materlals and Mechanics Res. Center, Massachusetts, AMMRC MS 8203, 221-119 (1982).

[23] G. C. Sih, Handbook of stress intensity factors. Lehigh University, Pennsylvania (1973).

[24] J. S. Cullen, Mode I delamination of unidirectional graphite/epoxy composite under complex load histories. Master thesis, Texas A\&M University (1981).

[25] J. M. Whitney, Characterization of interlaminar fracture toughness. Proc. of Eighth Annual Mechanics of Composites Review, AFWAL-TR-83-4005, 73-84 (1983). 
[26] D. H. Kaelble, P. J. Dynes, L. W. Crane, and L. Maus, Kinetics of environmental degradation in graphite/epoxy laminates. ASTM STP 580, 247-262 (1975).

[27] J. L. McCall and P. M. French, Metallography in fallure analysis. Plenum Press, New York (1977).

[28] K. M. Liechti, J. E. Masters, D. A. Ulman, and M. W. Lehman, SEM/TEM fractography of composite materials. Afr Force Wright Aeronautfcal laboratories, WP AFB, Ohio, AFWAL-TR-82-4085 (1982).

[29] D. Purslow, Some fundamental aspects of composite fractography. Composites 11, 241-247 (1981).

[30] R. E. Herteri, Fractography of graphite epoxy composites. SAMPE Quarterly, 7-12 (1982).

[31] R. A. Kline and F. H. Chang, Composite failure surface analysis. J. Comp. Mat. 14, 315-324 (1980). 
Table 1

\begin{tabular}{|c|c|c|c|c|c|}
\hline Lay-up & $\begin{array}{l}\text { Exposure } \\
\text { condition }\end{array}$ & $\begin{array}{l}\text { Moisture level } \\
\text { (\% water) }\end{array}$ & $\begin{array}{c}\text { Test } \\
\text { condition }\end{array}$ & $\begin{array}{c}G_{I c_{2}} \\
\left(\mathrm{~J} / \mathrm{m}^{2}\right)\end{array}$ & $\begin{array}{c}\text { AE count } \\
\text { density, } n \\
\left(\text { counts } / \mathrm{mm}^{2}\right)\end{array}$ \\
\hline \multirow{5}{*}[0]{$_{16}$} & Dry & 0 & \multirow[t]{5}{*}{$\begin{array}{l}\text { Room } \\
\text { environment }\end{array}$} & 103 & 572 \\
\hline & $\begin{array}{l}70^{\circ} \mathrm{C} / 50 \% \mathrm{RH} \\
(13 \text { days })\end{array}$ & .44 & & 106 & 395 \\
\hline & $\begin{array}{l}70^{\circ} \mathrm{C} / 50 \% \mathrm{RH} \\
(98 \text { days) }\end{array}$ & .56 & & 106 & 373 \\
\hline & $\begin{array}{l}70^{\circ} \mathrm{C} / \mathrm{H}_{2} \mathrm{O} \\
(13 \text { days })\end{array}$ & 1.06 & & 128 & 402 \\
\hline & $\begin{array}{l}70^{\circ} \mathrm{C} / \mathrm{H}_{2} \mathrm{O} \\
(62 \text { days })\end{array}$ & $2.1 \%$ & & 129 & 281 \\
\hline \multirow{2}{*}[0]{$_{20}$} & Dry & 0 & $\begin{array}{l}\text { Room } \\
\text { envi ronment }\end{array}$ & 103 & -- \\
\hline & $\begin{array}{l}127^{\circ} \mathrm{C} \\
(2 \mathrm{hr})\end{array}$ & 0 & $127^{\circ} \mathrm{C}$ & 121 & --- \\
\hline \multirow{2}{*}[0]{$_{26}$} & Dry & 0 & $\begin{array}{l}\text { Room } \\
\text { envi ronment }\end{array}$ & 121 & 537 \\
\hline & $\begin{array}{l}70^{\circ} \mathrm{C} / \mathrm{H}_{2} \mathrm{O} \\
(109 \text { days })\end{array}$ & 1.50 & $\begin{array}{l}\text { Room } \\
\text { envi ronment }\end{array}$ & 138 & 284 \\
\hline
\end{tabular}


Table 2

\begin{tabular}{|c|c|c|c|c|c|}
\hline S. No. & $\begin{array}{l}\text { Material } \\
\text { system }\end{array}$ & $\begin{array}{c}\text { Dry } \\
\text { GIc } \\
\left(\mathrm{J} / \mathrm{m}^{2}\right)\end{array}$ & $\begin{array}{c}\text { Wet } \\
\text { GIc } \\
\left(\mathrm{J} / \mathrm{m}^{2}\right)\end{array}$ & $\begin{array}{l}\text { Test } \\
\text { method }\end{array}$ & Reference \\
\hline 1 & $\mathrm{~T} 300 / 934$ & 103 & 129 & DCB & Present work \\
\hline 2 & AS $3501-6$ & 130 & 168 & & W1IkIns [18] \\
\hline 3 & $\mathrm{~T} 300 / 5208$ & 88 & -- & & W1lkins et al. [1] \\
\hline 4 & AS $3501-2$ & 155 & -- & & Vanderkley [17] \\
\hline 5 & AS $3501-2$ & 128 & -- & & Cullen $[24]$ \\
\hline 6 & AS $3501-2$ & 132 & --- & & Whd tney [25] \\
\hline 7 & T300-6K/V378A & 149 & 152 & & Wilkins [18] \\
\hline 8 & T300/V 378A & 79 & --- & & Whit tney [25] \\
\hline 9 & AS 1/polysu1fone & 655 & --- & & Whit tney [25] \\
\hline 10 & $\begin{array}{l}\text { Scotchply } \\
\text { E glass/epoxy }\end{array}$ & $525-1000$ & --- & & Devitt et a1. [15] \\
\hline 11 & $\begin{array}{l}\text { Glass fiber } \\
\text { polyester }\end{array}$ & 800 & 950 & $\begin{array}{c}\text { Width tapered } \\
\text { DCB }\end{array}$ & $\begin{array}{l}\text { Han and Koutosky } \\
{[14]}\end{array}$ \\
\hline 12 & $\begin{array}{l}\text { Epoxy (hexa- } \\
\text { hydrophthalic } \\
\text { anhydride } \\
\text { DGEBA) }\end{array}$ & 116 & -- & -- & Bascom et a1. [10] \\
\hline
\end{tabular}


Table 3

\begin{tabular}{|c|c|c|c|c|c|}
\hline $\begin{array}{l}\text { Exposure } \\
\text { condition }\end{array}$ & $\begin{array}{c}\text { Moisture } \\
\text { level } \\
\text { (\% water) }\end{array}$ & $\left(\mathrm{MPa}_{\mathrm{Ic}} \sqrt{\mathrm{m}}\right)$ & ${ }_{(\%)}^{c . v}{ }^{1}$ & $\underset{\left(\mathrm{J} / \mathrm{m}^{2}\right)}{\mathrm{G}_{\mathrm{I}}}$ & $\underset{(\%)}{c \cdot v \cdot 1}$ \\
\hline Dry. & 0 & 2.39 & 5.9 & 414 & 12.0 \\
\hline $\begin{array}{c}70^{\circ} \mathrm{C} / 50 \% \text { RH } \\
\text { (62 days) }\end{array}$ & 0.89 & 2.19 & 2.9 & 345 & 5.7 \\
\hline $\begin{array}{l}70^{\circ} \mathrm{C} / \mathrm{H}_{2} \mathrm{O} \\
(58 \text { days })\end{array}$ & 1.5 & 1.75 & 2.7 & 222 & 5.5 \\
\hline
\end{tabular}


Table 4

\begin{tabular}{|c|c|c|c|c|c|}
\hline S. No. & $\begin{array}{c}\text { Material } \\
\text { system }\end{array}$ & 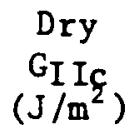 & $\begin{array}{c}\text { Wet } \\
\text { GII }_{\mathrm{f}} \\
\left(\mathrm{J} / \mathrm{m}^{2}\right)\end{array}$ & $\begin{array}{c}\text { Test } \\
\text { method }\end{array}$ & Reference \\
\hline 1 & $\mathrm{~T} 300 / 934$ & 272 & 239 & CLS & Present study \\
\hline 2 & $\mathrm{~T} 300 / 5208$ & 154 & --- & CLS & Wilkins et al. [1] \\
\hline 3 & AS $3501-6$ & 322 & 294 & CLS & Wilkins [18] \\
\hline 4 & $\mathrm{~T} 300-6 \mathrm{~K} / \mathrm{V} 378 \mathrm{~A}$ & 181 & 149 & CLS & Wilkins [18] \\
\hline
\end{tabular}


TABLE TITLES

Table 1. A data summary of Mode I delamination.

Table 2. A summary of interlaminar fracture energies observed for a number of composite systems.

Table 3. A data summary of transverse cracking.

Table 4. A summary of Mode II fracture energles observed for a number of composite systems. 


\section{FIGURE TITLES}

Fig. 1. Double cantilever beam (DCB) specimen used for Mode I loading.

Fig. 2. Cracked-lap-shear (CLS) specimen used for mixed mode loading.

Fig. 3. Typical variation in compliance with delamination length for Mode I delamination.

Fig. 4 Typical variation in critical load with delamination length for Mode I delamination.

Fig. 5. Typical variation in compliance with delamination length for mixed Mode delamination.

Fig. 6. Typlcal load-displacement curves for Mode I delamination in dry $[0]_{16}$ laminate.

Fig. 7. Typical load-displacement curves for Mode I delamination in wet $(w=2.1 \%),[0]_{16}$ laminate after 62 days immersion in $70^{\circ} \mathrm{C}$ water.

Fig. 8. Optical mlcrograph of the fracture surface of wet $(w=2.1 \%)$, $[0]_{16}$ laminate formed during Mode I delamination. Regions of rapid crack growth are darker than regions of slower crack growth.

Fig. 9 Typical AE response during delamination; (a) dry, (b) wet $(w=2.1 \%)$.

Fig. 10. AE counts per unit specimen width as a function of delamination growth for dry specimens. 
Fig. 11. AE counts per unit crack surface area, $n$, formed during delamination growth in $[0]_{16}$ laminates containing various moisture contents (exposure $-70^{\circ} \mathrm{C} /$ water).

F1g. 12. Varlation in $G_{I c}$ as a function of molsture content for Mode I delamination.

Fig. 13. Variation in $G_{I c}$ as a function of temperature for Mode I delamination in dry, $[0]_{20}$ laminates.

Fig. 14. Typical load displacement curves for mixed-mode delamination using cracked-lap-shear specimens.

Fig. 15. Variation in $G_{I I c}$ as a function of moisture content for Mode II delamination.

Fig. 16. Typical fracture features observed under Mode I delamination.

Fig. 17. Typical fracture features associated with transverse cracking.

Fig. 18. Typical fracture features observed under mixed-mode loading. 


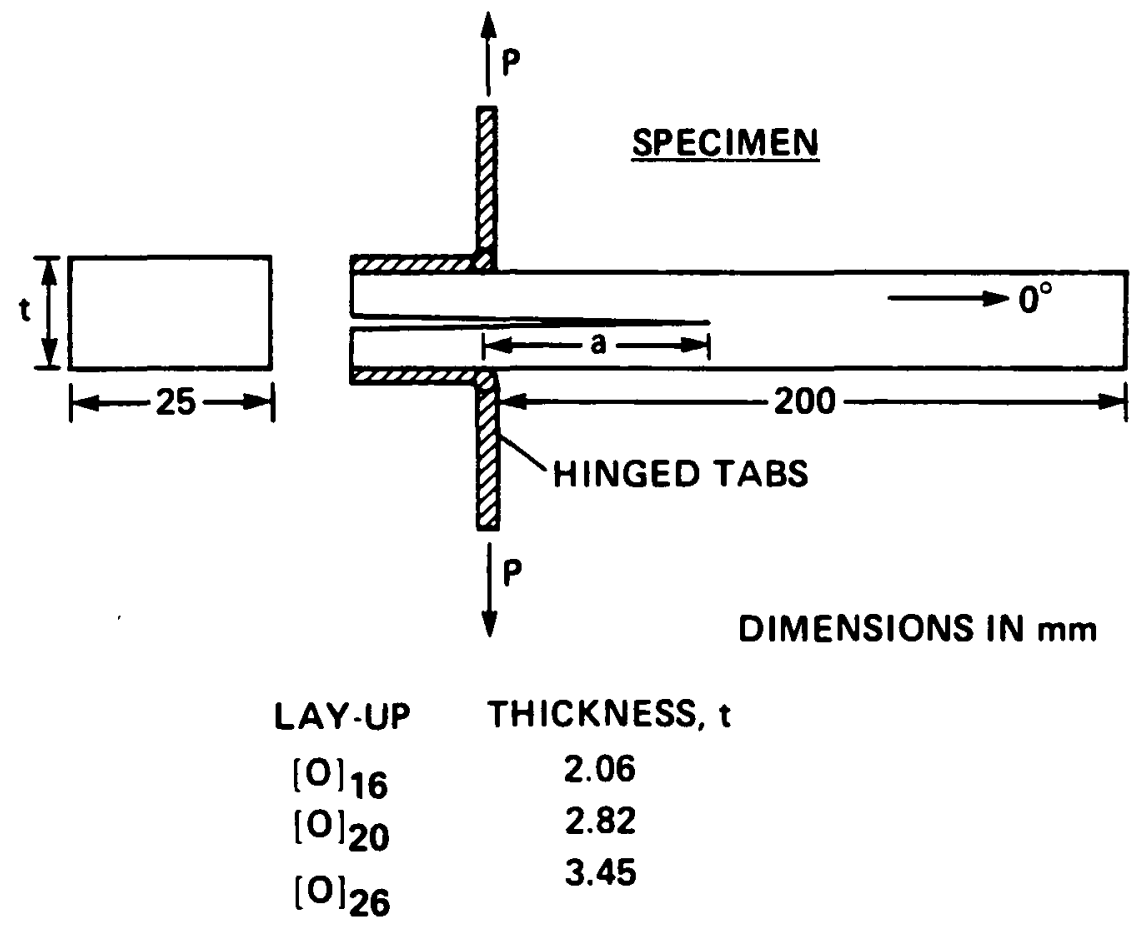

Fig. I 

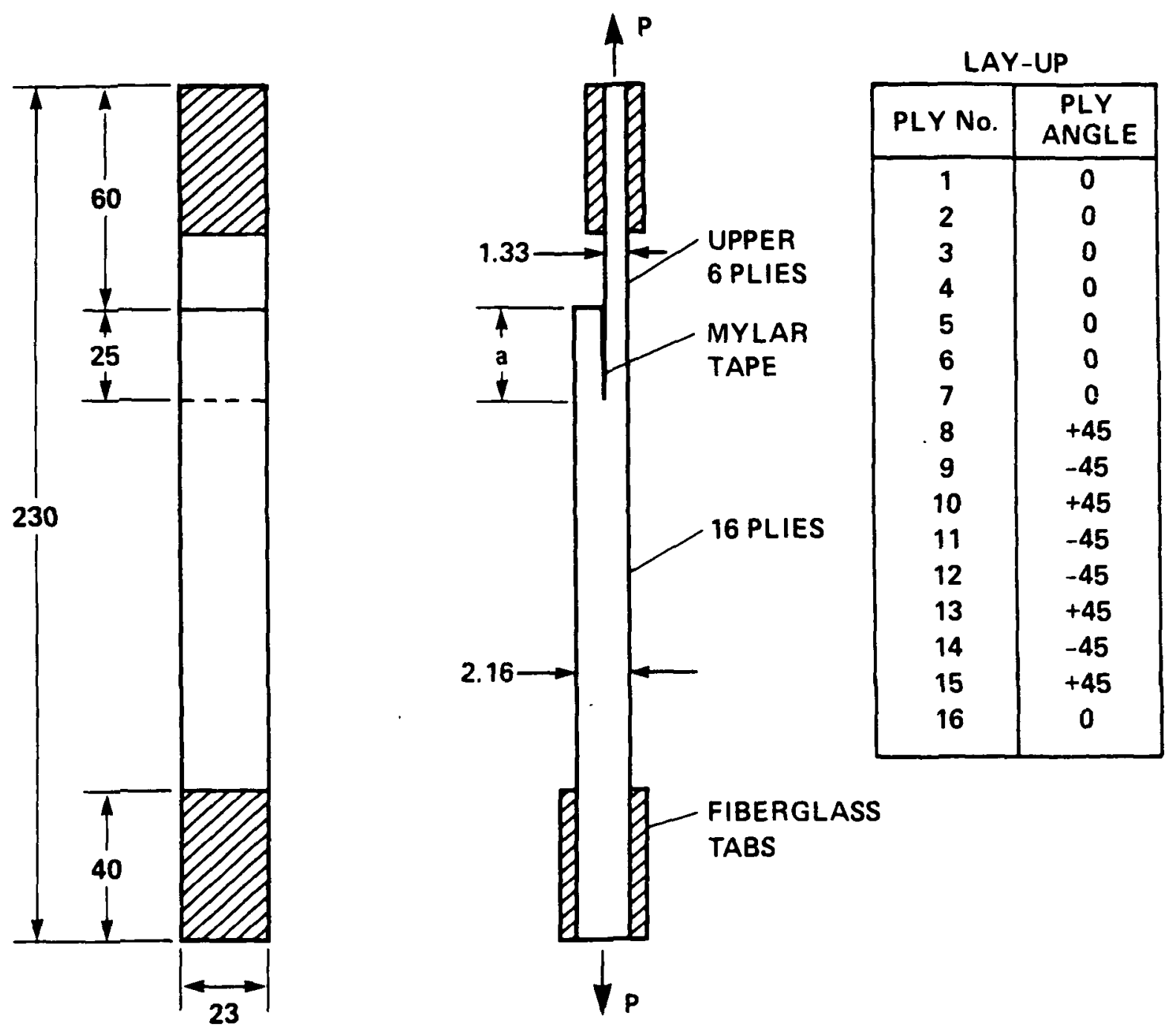

(DIMENSIONS IN mm)

Fig. 2 


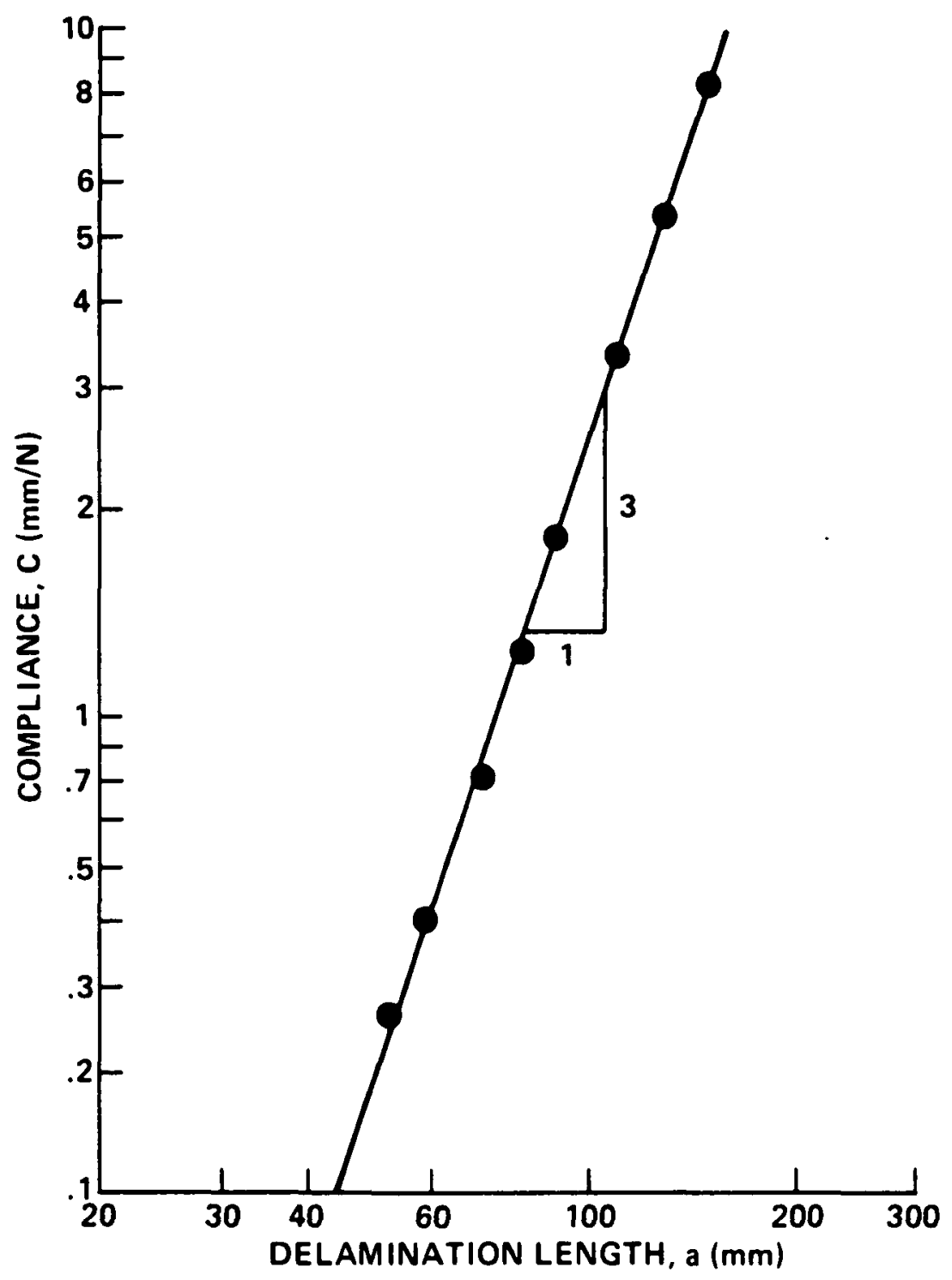

Fig. 3 


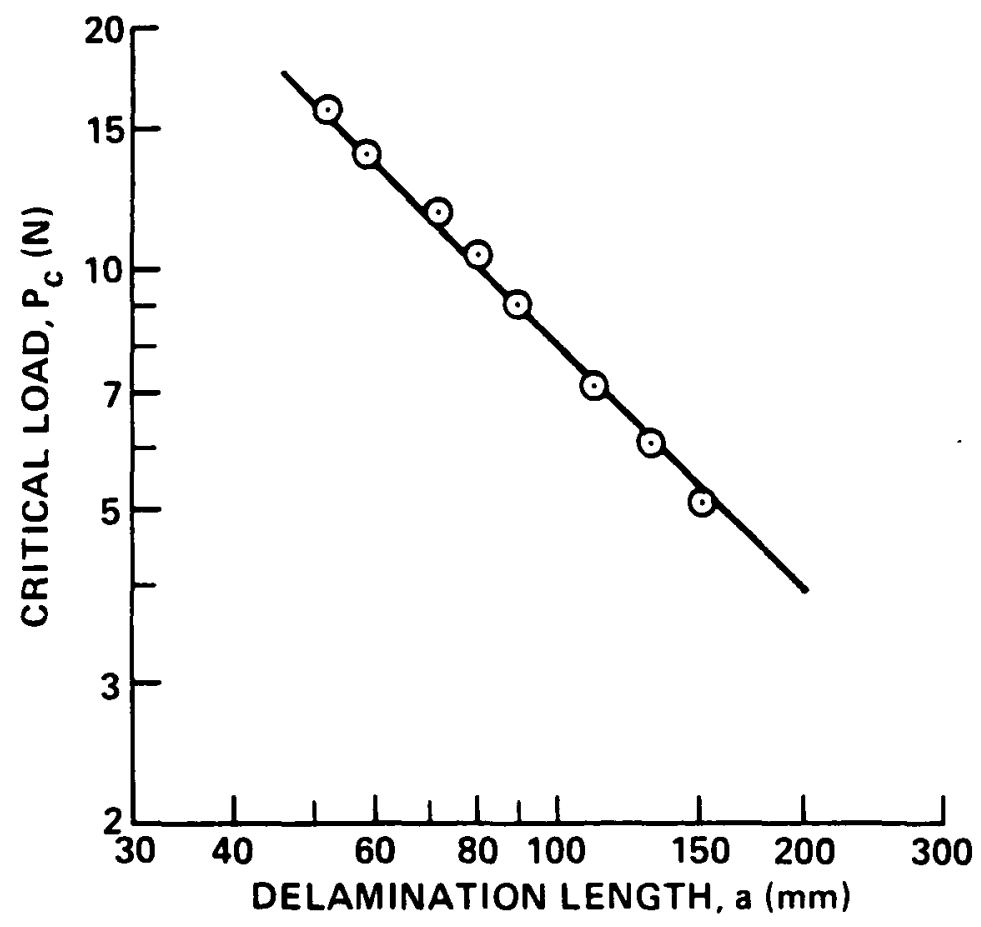

Fig. 4 


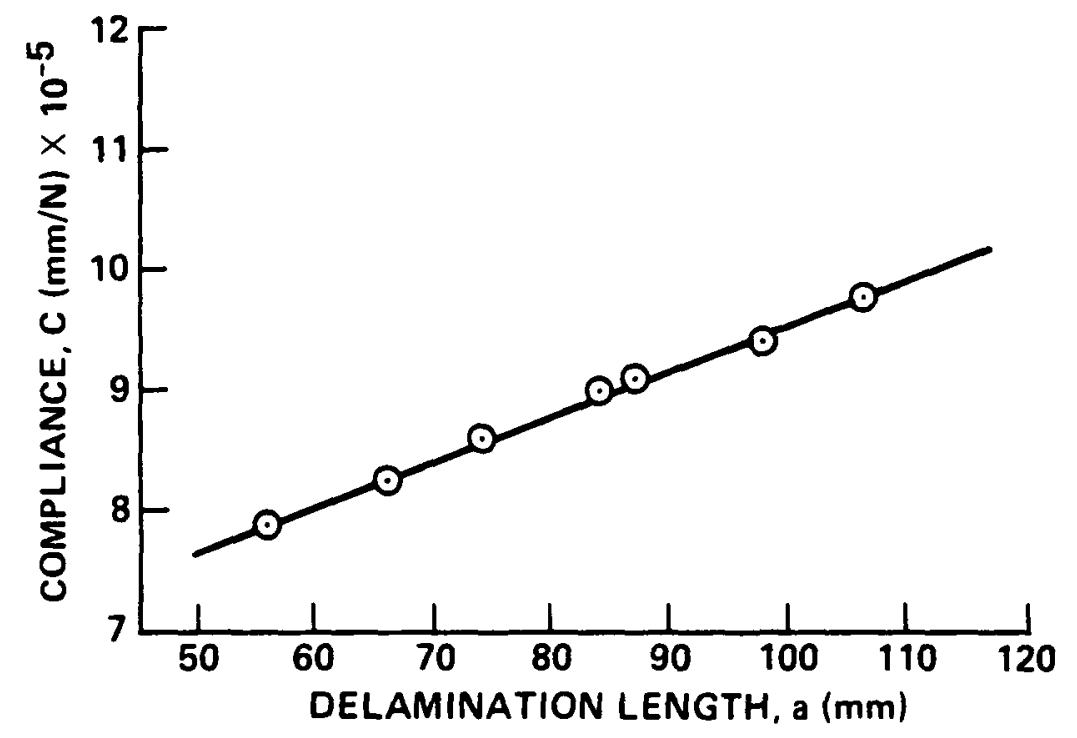

Fig. 5 


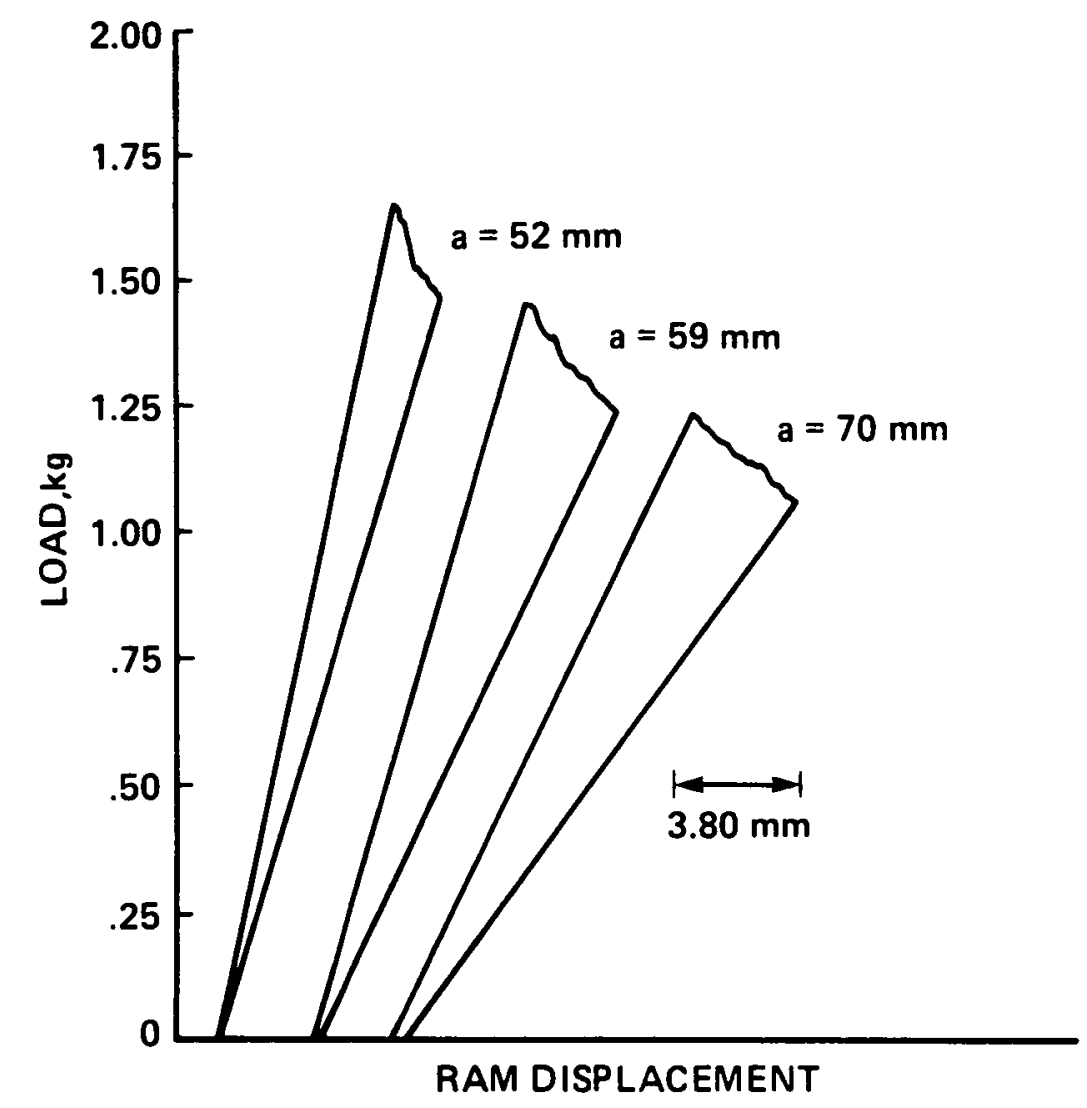

Fis. 6 


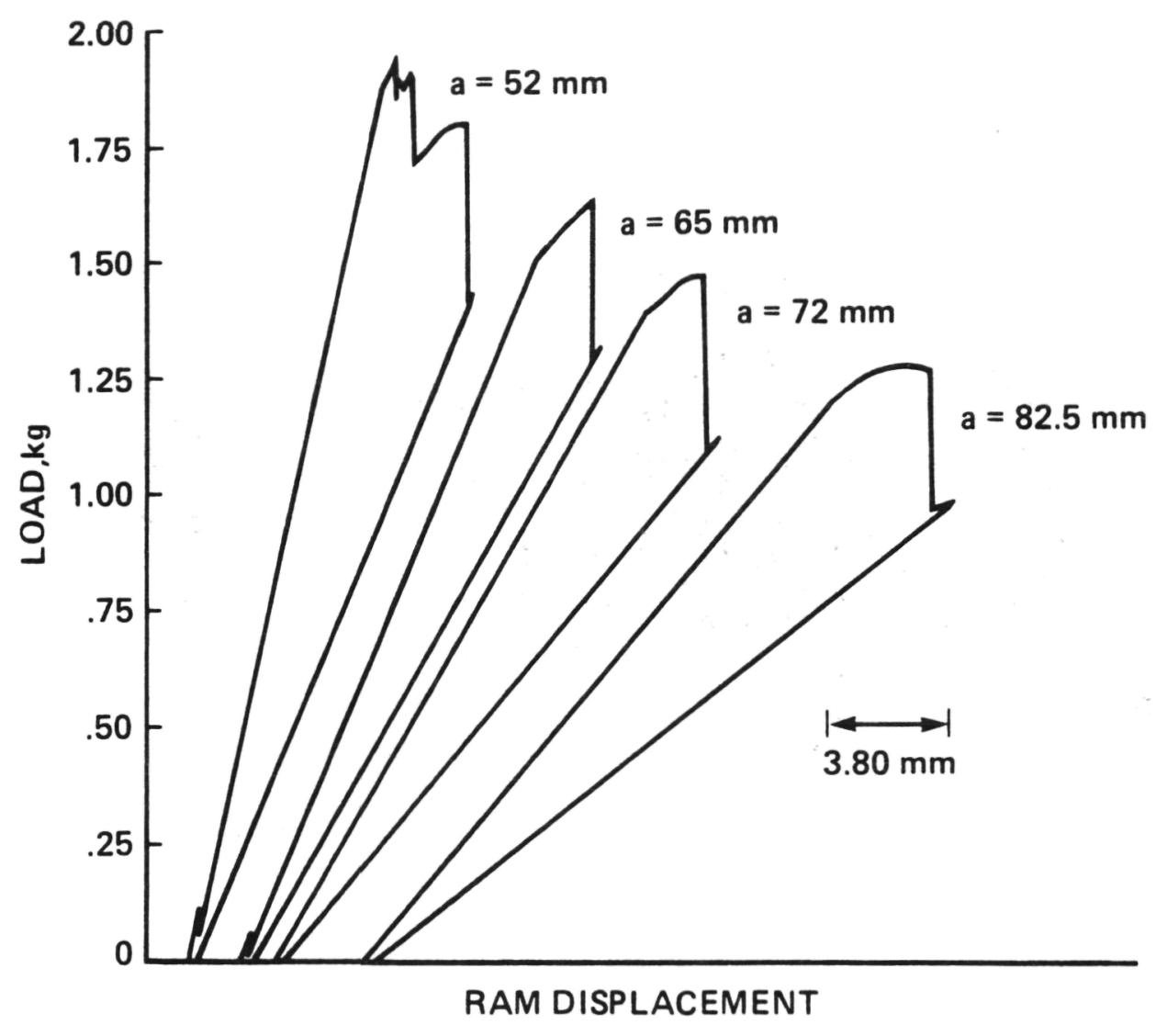

Fig. 7 


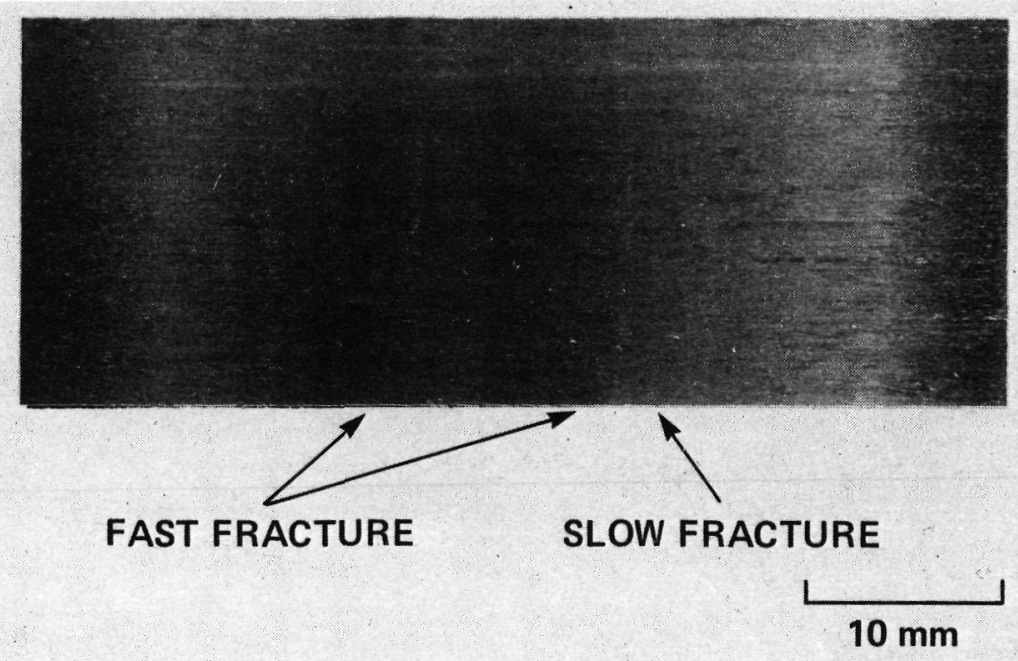

Fig. 8 

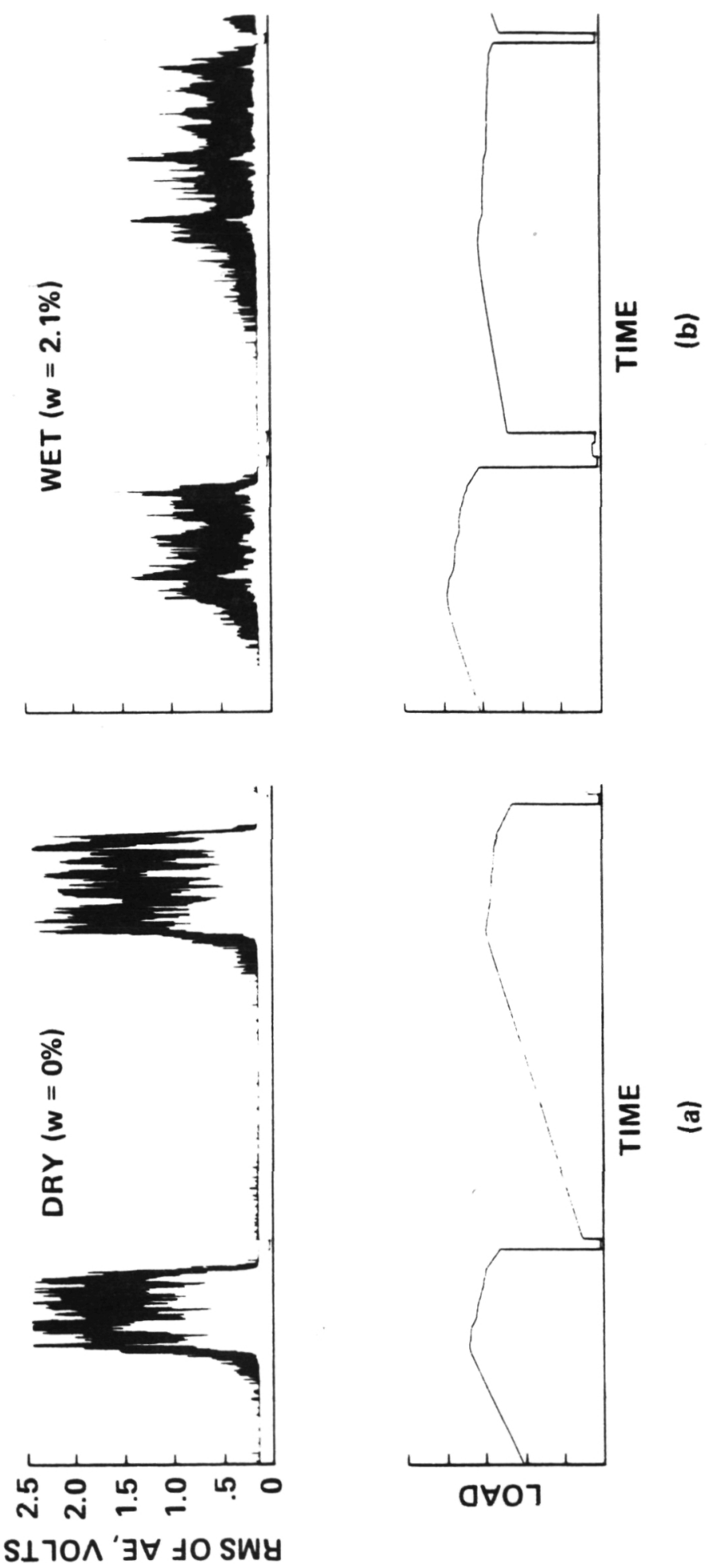

$a$
$\infty$
0
0
0 


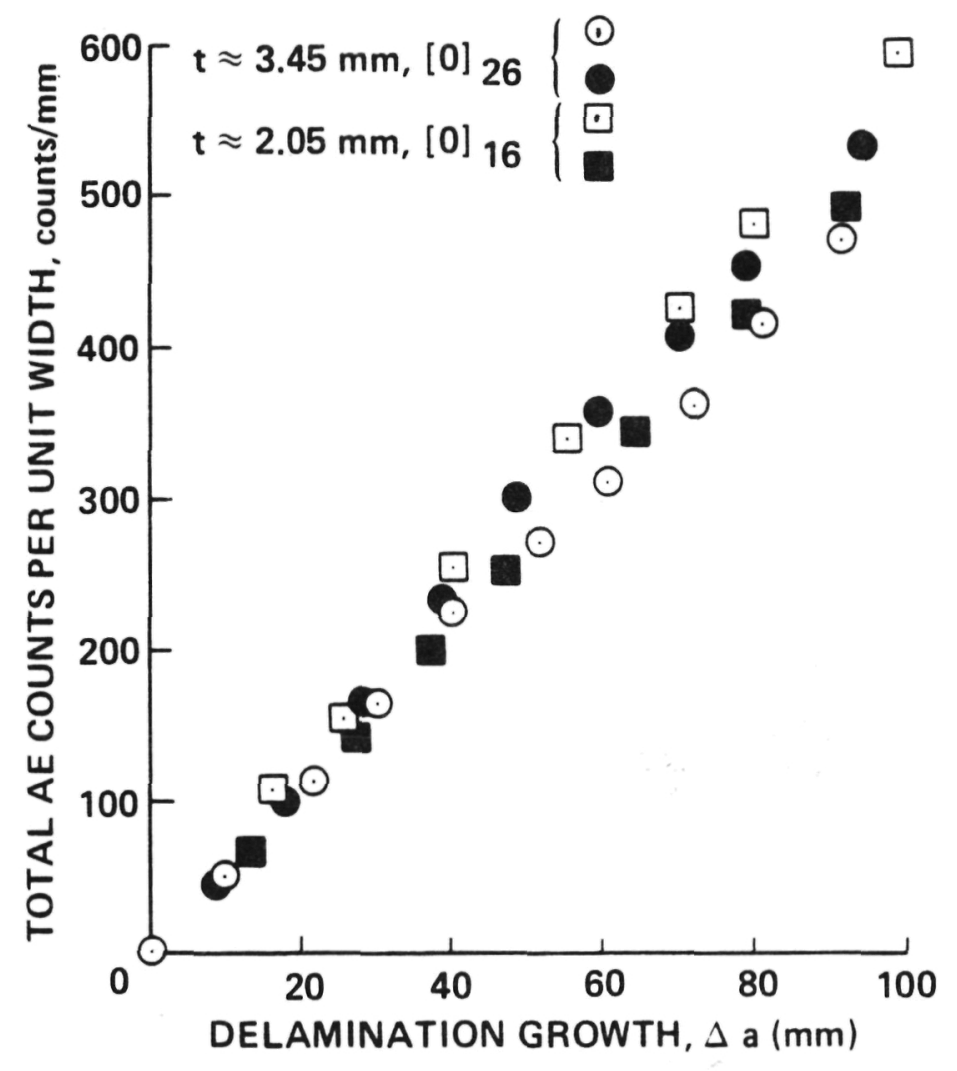

Fig. 10 


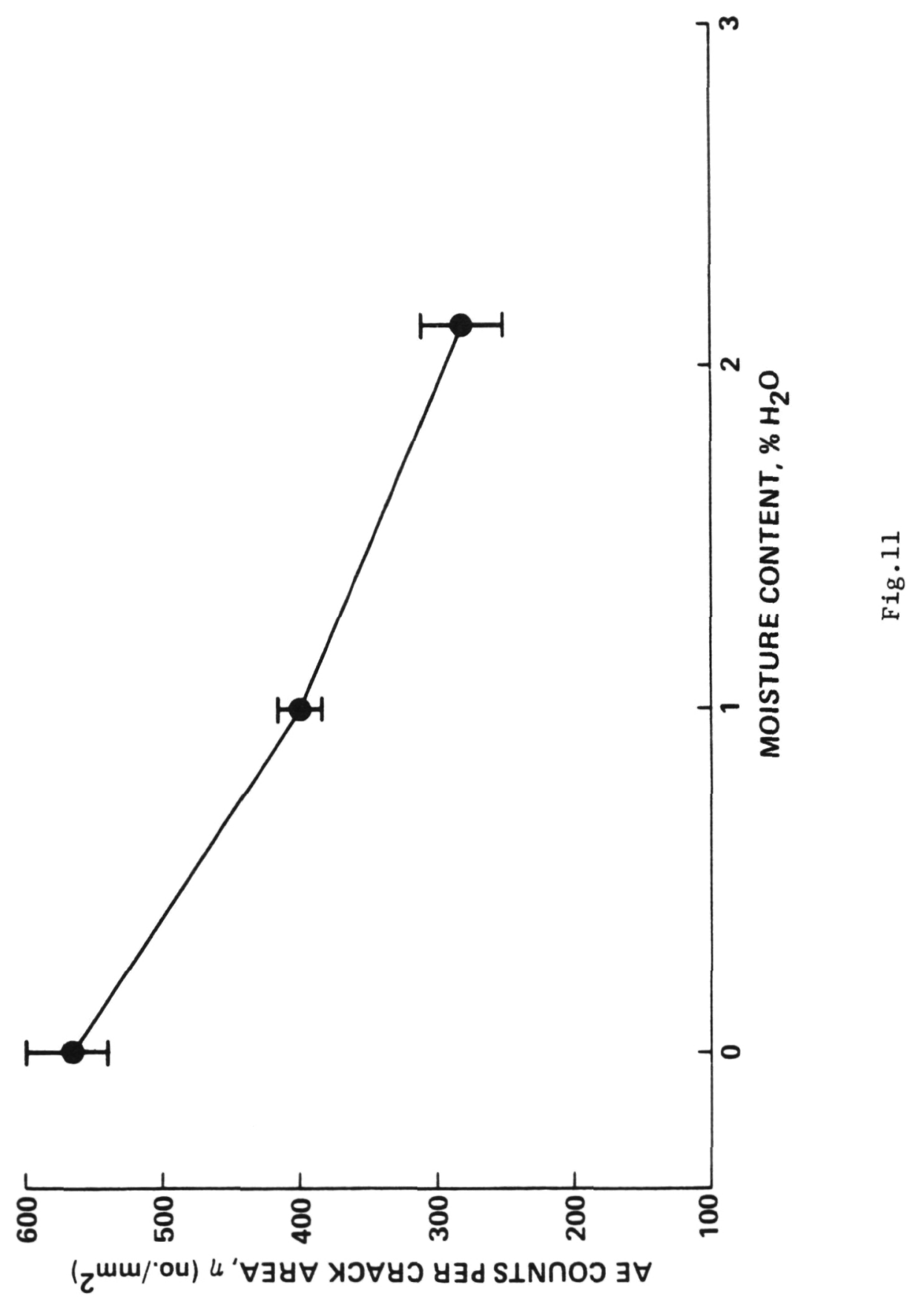




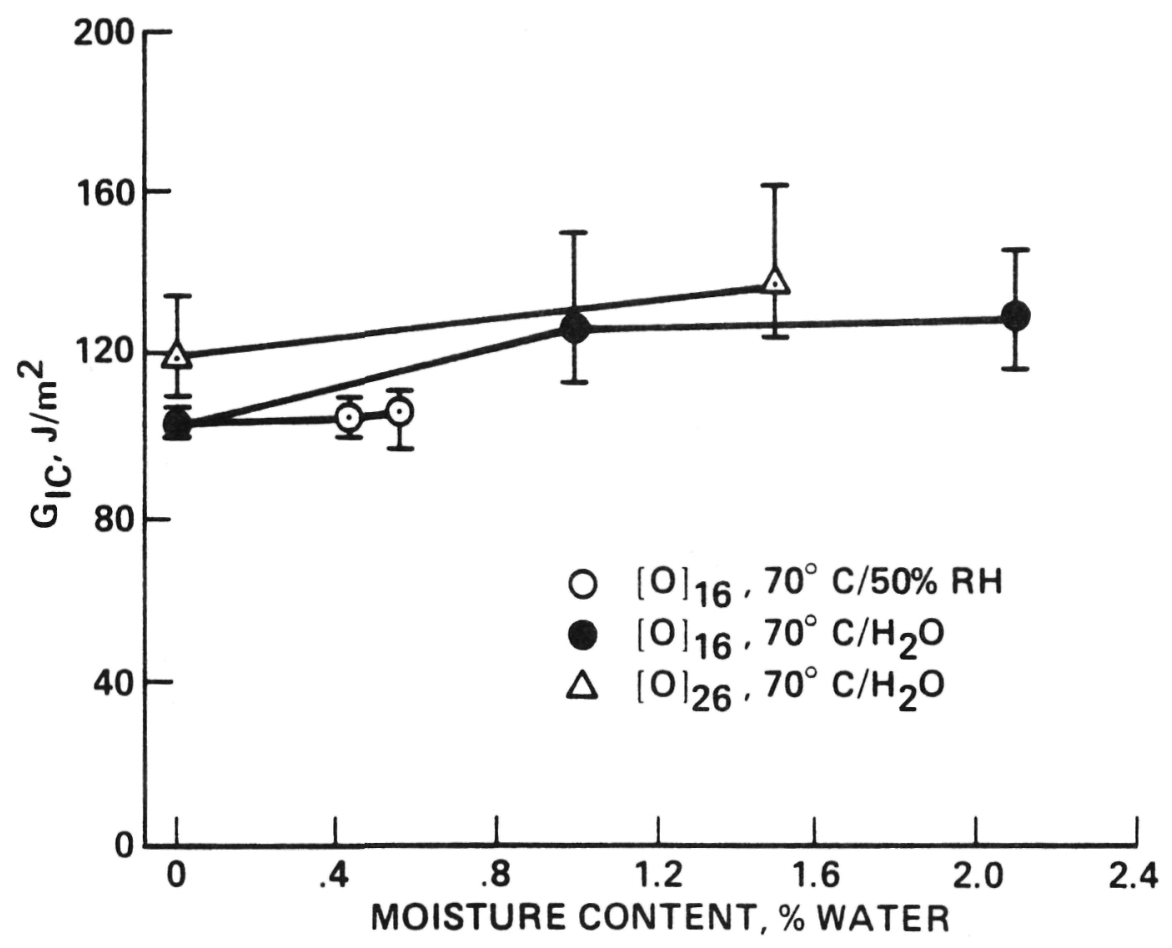

Fig. 12 


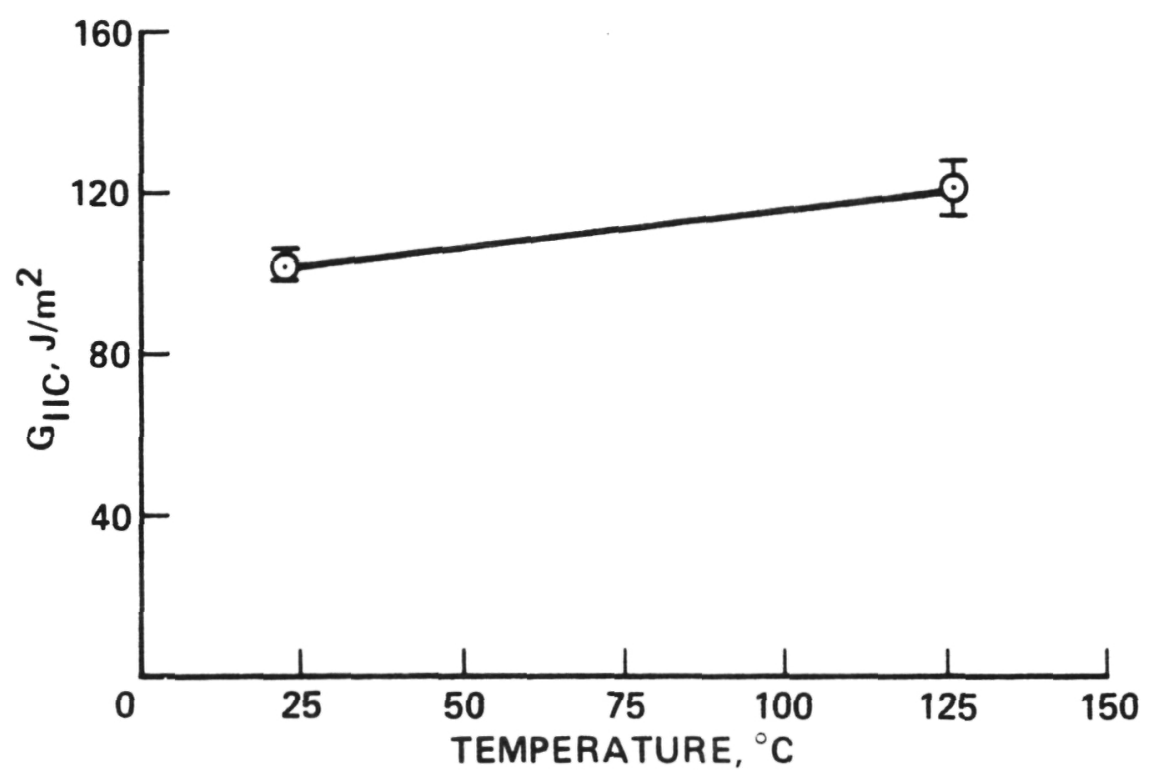

Fig. 13 


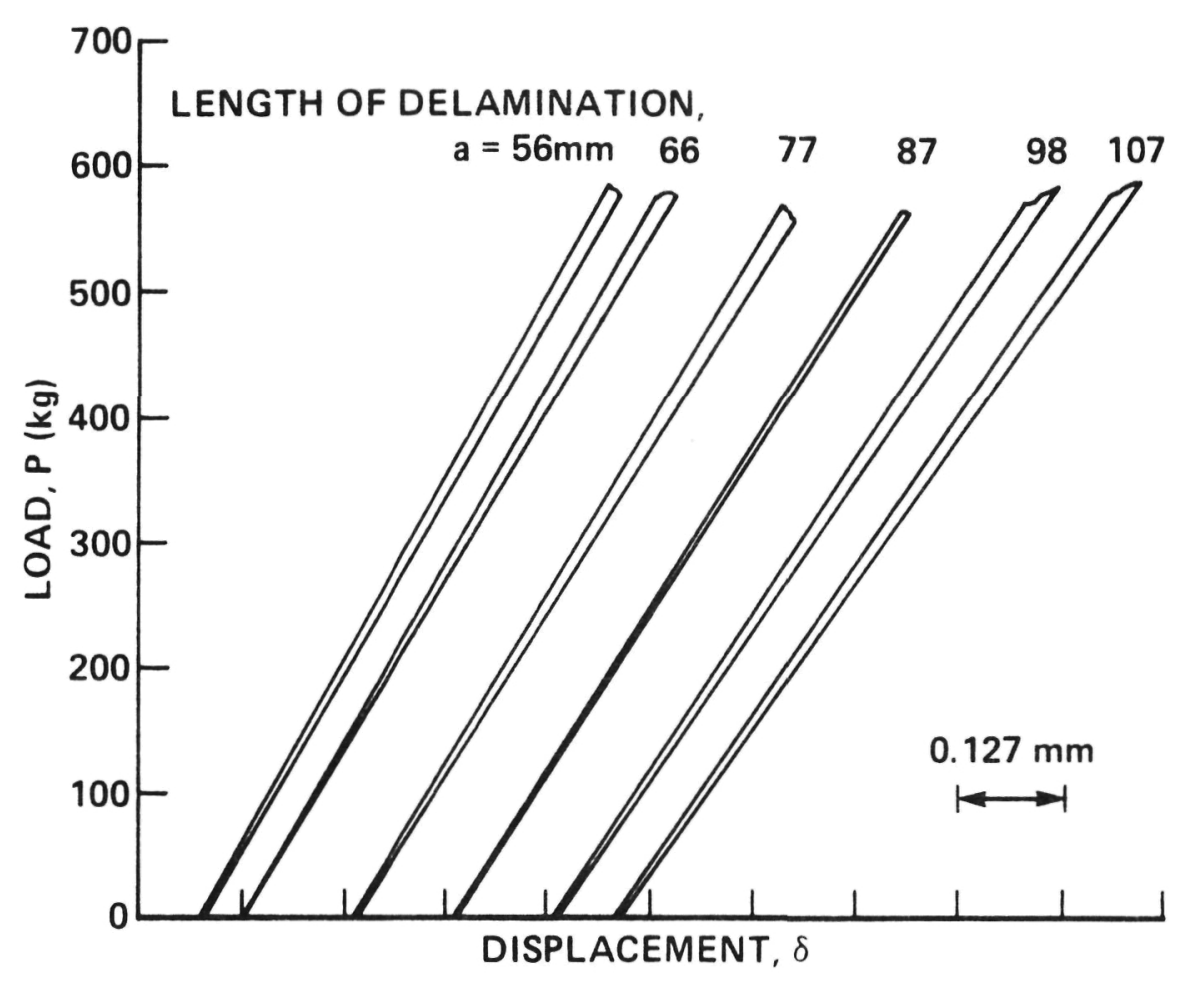

Fig. 14 


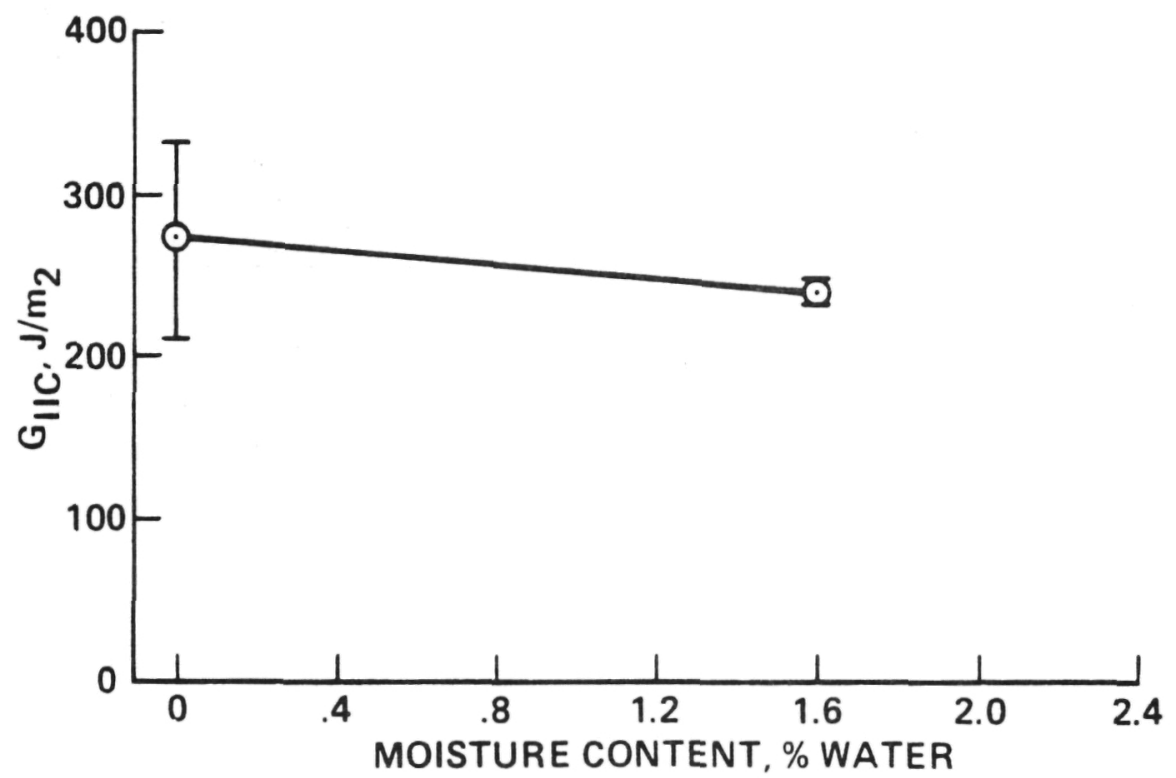

Fig. 15 


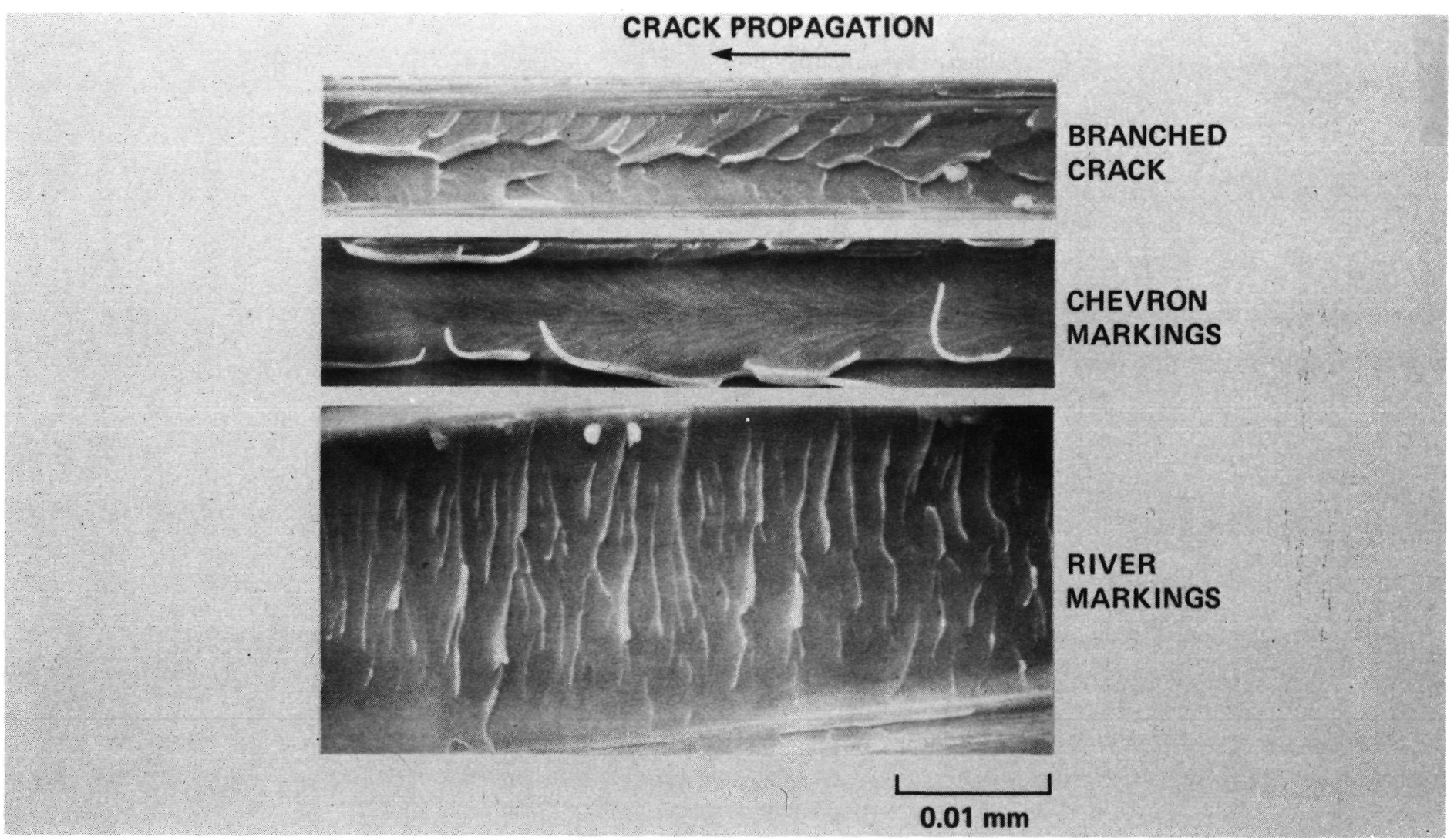

Fig. 16 


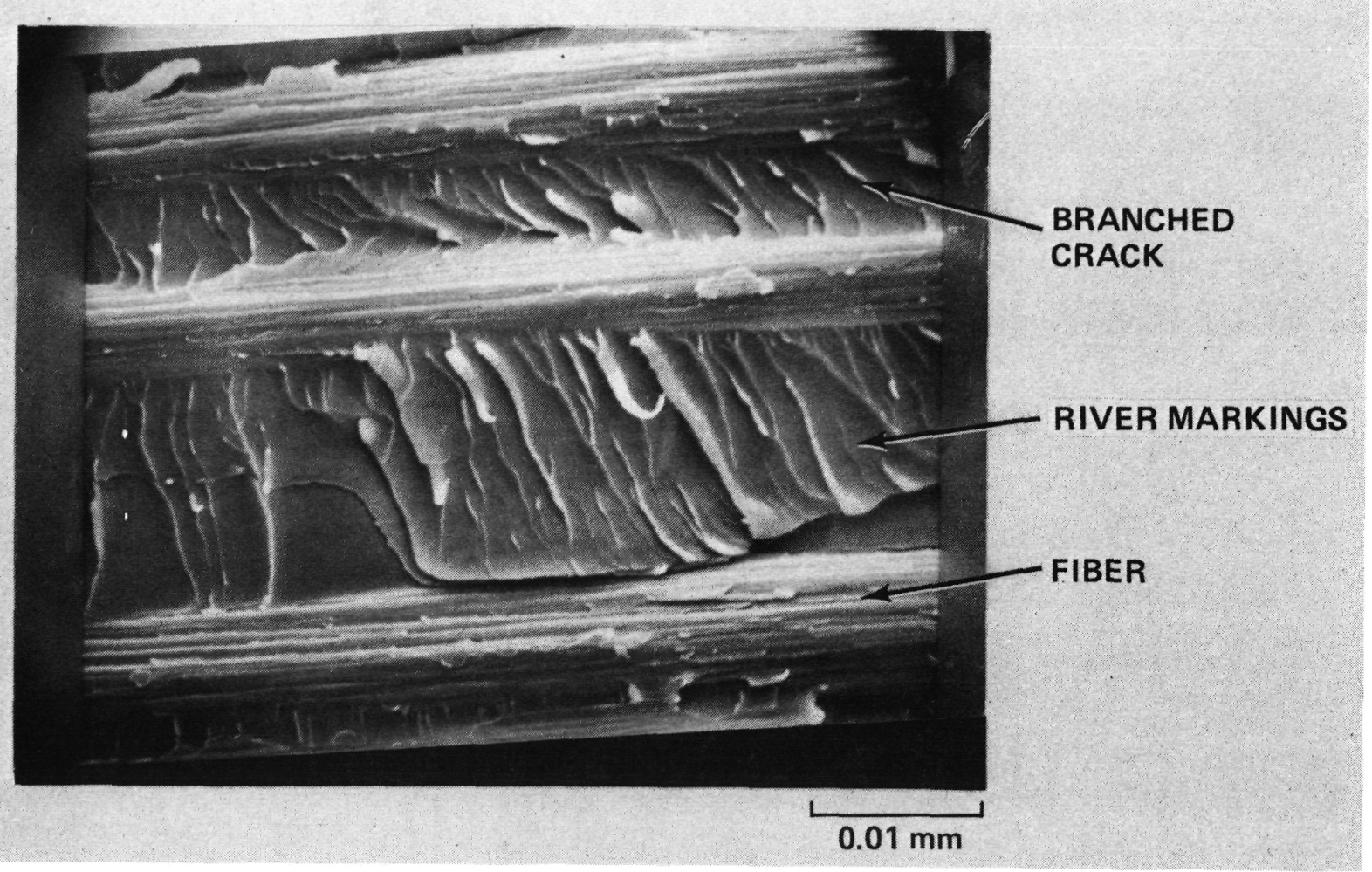

Fig. 17 


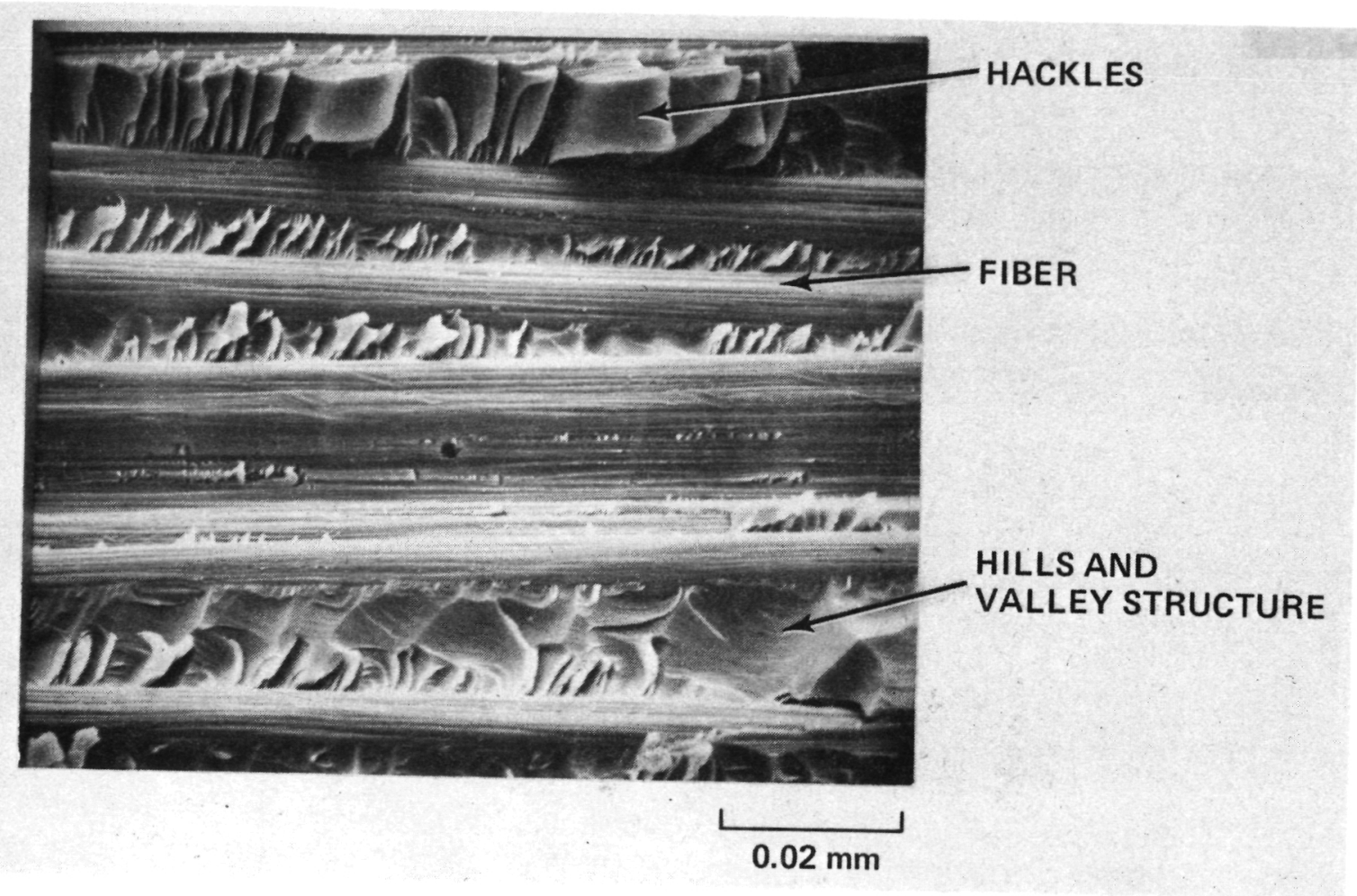

Fig. 18 


\begin{tabular}{|c|c|c|c|c|}
\hline \multicolumn{2}{|c|}{$\begin{array}{l}\text { 1. Report No. } \\
\text { NASA TM } 85935\end{array}$} & 2. Government Accession No. & \multicolumn{2}{|c|}{ 3. Recipient's Catalog No. } \\
\hline & \multirow{2}{*}{\multicolumn{2}{|c|}{$\begin{array}{l}\text { Title and Subtitle } \\
\text { Hyg rothermal Influence on Delamation Behavior } \\
\text { of Graphite/Epoxy Laminates }\end{array}$}} & \multicolumn{2}{|l|}{$\begin{array}{l}\text { 5. Report Date } \\
\text { March } 1984\end{array}$} \\
\hline & & & \multicolumn{2}{|c|}{$\begin{array}{l}\text { 6. Performing Organization Code } \\
\text { ATP }\end{array}$} \\
\hline \multicolumn{3}{|c|}{ 7. Author(s) } & \multicolumn{2}{|c|}{$\begin{array}{l}\text { 8. Performing Organization Report No. } \\
\text { A-9705 }\end{array}$} \\
\hline \multicolumn{3}{|c|}{ Amar Garg and Ori Ishai } & \multirow{2}{*}{\multicolumn{2}{|c|}{ 10. Work Unit No. }} \\
\hline \multirow{2}{*}{\multicolumn{3}{|c|}{$\begin{array}{l}\text { 9. Performing Organization Name and Address } \\
\text { Ames Research Center. Moffett Field CA } 94035\end{array}$}} & \multirow{2}{*}{\multicolumn{2}{|c|}{$\frac{T-9516}{\text { 11. Contract or Grant No. }}$}} \\
\hline \multirow{2}{*}{\multicolumn{3}{|c|}{ Ames Research Center, Moffett Field, CA 94035}} & & 11. Contract or Grant No. \\
\hline & & & \multicolumn{2}{|c|}{$\begin{array}{l}\text { 13. Type of Report and Period Covered } \\
\text { Technical Memorandum }\end{array}$} \\
\hline & \multicolumn{2}{|c|}{$\begin{array}{l}\text { National Aeronautics and Space Administration } \\
\text { Washington DC, } 29546\end{array}$} & $\begin{array}{l}\text { 14. Sponsoring Agency Code } \\
505-33-12\end{array}$ & $\frac{\text { Technical Memorandum }}{\text { 14. Sponsoring Agency Code }}$ \\
\hline \multicolumn{5}{|c|}{$\begin{array}{ll}\text { Point of contact: } & \text { Amar Garg, Ames Research Center, MS } 244-6, \\
& \text { Moffett Field, CA (415) 965-6660 or FTS 448-6660 }\end{array}$} \\
\hline \multicolumn{5}{|c|}{$\begin{array}{l}\text { 16. Abstract } \\
\text { The hygrothermal effect on the fracture behavior of graphite/epoxy } \\
\text { laminates has been investigated as part of an overall effort to develop } \\
\text { a methodology for damage-tolerance predictions in advanced composite } \\
\text { materials. Several T300/934 laminates were tested using a number of } \\
\text { specimen configurations (double cantilever, compact tension, and cracked } \\
\text { lap shear) in order to evaluate the effects of temperature and humidity } \\
\text { on delamination fracture toughness under Mode I and Mode II loading. } \\
\text { The specimens were exposed to different humidity levels and temperatures } \\
\text { for varying periods of time prior to testing. The pre-exposed specimens } \\
\text { were tested under room conditions, and fracture energies during initia- } \\
\text { tion and propagation were estimated. Acoustic emission was used to } \\
\text { detect crack initiation. It was indicated that moisture has a slightly } \\
\text { beneficial influence on fracture toughness or critical strain energy } \\
\text { release rate during Mode I delamination, but has a slightly deleterious } \\
\text { effect on Mode II delamation and Mode I transverse cracking. The } \\
\text { failed specimens were examined by SEM and topographical differences due } \\
\text { to fracture modes were identified. The effect of moisture on fracture } \\
\text { topography could not be distinguished. }\end{array}$} \\
\hline & $\begin{array}{l}\text { Key Words (Suggested by Aut } \\
\text { Delamination } \\
\text { Fracture } \\
\text { Composites } \\
\text { Graphite/Epoxy }\end{array}$ & 18. Distribution & Subject Cate & ory: 39 \\
\hline & $\begin{array}{l}\text { Security Classif. lof this report } \\
\text { Unc1. }\end{array}$ & $\begin{array}{l}\text { 20. Security Classif. (of this page) } \\
\text { Uncl. }\end{array}$ & $\begin{array}{l}\text { 21. No. of Pages } \\
47\end{array}$ & $\begin{array}{r}\text { 22. Price } \\
\mathrm{A0} 3\end{array}$ \\
\hline
\end{tabular}

"For sale by the National Technical Information Service, Springfield, Virginia 22161 